\title{
Evaluation of Lactoferrin Immunomodulatory Effect on the Immune Response of Broiler Chickens
}

Enany, M.E. ${ }^{l}$; Algammal, A.M. ${ }^{l}$; Solimane, R.T ${ }^{2}$; El-Sissi, A.F. ${ }^{3}$ and Hebashy A.A. ${ }^{3}$

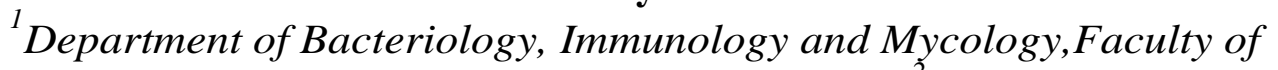
Veterinary Medicine, Suez Canal University ${ }^{2}$ Department of Microbiology, Faculty of Veterinary Medicine, Cairo University

${ }^{3}$ Department of Immunology, Animal Health Research Institute, Dokki

\begin{abstract}
Immunomodulators are substances that able to regulate or modulate immune responses. In order to investigate the lactoferrin effect on the immune system of broiler chickens, one hundred twenty (1-dayold) chicks of both sexes were randomly allocated into 2 dietary groups (60 chicks/group), group1 (G1): chicks were offered basal diets and kept as control group, group2 (G2): Chicks were offered basal diets supplemented with lactoferrin $(250 \mathrm{mg} / \mathrm{kg}$ diet for 6 weeks). Evaluating the effects of dietary supplementation with lactoferrin on growth performance of broiler chicks, humeral immunity by measuring antibody titer against Newcastle (ND) and Avian influenza (AIV)vaccine, and on innate immunity by measuring some functions of peripheral blood monocytes (PBM) as phagocytic activity, fungicidal activity, nitric oxide (NO) production and reactive oxygen species (ROS) production by tetrazolium reduction test. To study antibacterial effect of lactoferrin, challenge test was carried out using virulent $E$. coli strain .The results revealed that, lactoferrin improve growth performance and could stimulate the humeral immunity by increasing the antibody titer aginst ND and AIV vaccine.Also lactoferrin could enhance the innate immunity by significant increasing of phagocytic and Fungicidal activities of PBM and its production of ROS and NO. Lactoferrin have the ability to protect broiler chickens from virulent agents as E. coli. Therefore, lactoferrin may be used as immunostimulant, growth promoters and antibacterial agent in broiler chickens.
\end{abstract}

Key words: Lactoferrin, broiler chickens, E. coli, humera immunity, challenge test,

\section{Introduction}

Microbes like bacteria, fungi, viruses, protozoa and multi-cellular parasites are prevalent in our environment and can cause disease if they multiply unchecked. The host defense against microbes is mediated by the early reactions of 
innate immunity and the later responses of adaptive immunity (Abbas and Litchman, 2005). The innate immune response is designed to rapidly alert the host of the presence of an invasive microbial pathogen that has breached the integument of multi-cellular eukaryotes (Opal and Esmon, 2003). It is able to eradicate microbial pathogens by activation of specific elements of adaptive immune response, i.e. cell mediated and humoral immunity via $\mathrm{T}$ and $\mathrm{B}$ cells, respectively. The immune system can be overwhelmed by the aforementioned factors; hence, the need for routine usage of immunomodulators (Porchezhian and Punniamurthy, 2006).

Immunomodulatory regimens offer an attractive approach as they often have fewer side effects than existing drugs; including less potential for creating resistance in microbial diseases (Masihi, 2001).Utilization of immuno-stimulants is one solution to improve the immunity of animals and to decrease their susceptibility to infectious disease (Lee et al.,2004).

Lactoferrin is considered to be a part of the innate immune system, at the same time, lactoferrin also takes part in specific immune reactions, but in an indirect way (Legrand et al., 2005) .Lactoferrin (an ironbinding glycoprotein), is a cellsecreted mediator that bridges innate and adaptive immune function in mammals. It is a pleiotropic molecule that directly assists in the influence of presenting cells for the development of $\mathrm{T}$ helper cell polarization. These findings are critically relevant in the development of both prophylactic and therapeutic interventions in humans. Understanding these particular effects of lactoferrin will provide a logical framework for determining its role in health and disease (Adlerova et al., 2008).Lactoferrin and its derivatives have pleiotropic functions including broad-spectrum anti-microbial activity, regulation of cell growth and differentiation, and modulation of inflammatory as well as humoral and cellular immune responses (Vander et al., 2007).

This work was planned to investigate the effect of dietary supplementation of lactoferrin on growth performance, humeral immune response against $\mathrm{ND}$ and AI vaccine and innate immune response by evaluate some function of peripheral blood monocyte cells (PBM). As well as evaluate the antibacterial effect of lactoferrin by challenge test using virulent $E$. coli.

\section{Materials and Methods 1-Experimental design:}

One hundred twenty (1-day-old) chicks (Hubbard breed) of both sexes were randomly allocated into 2 dietary groups (60 chicks/group). Group 1(G1): Chicks were offered basal diets and kept as control group. Group 2(G2): Chicks were offered basal diets supplemented with lactoferrin $(250 \mathrm{mg} / \mathrm{kg}$ diet $)$ 
(Robert, 2009) for 6 weeks (the experimental period).

2. Determination of growth Performance Parameters:

Birds were weighed at first day of age as one day-old weight and then final body weights (gm) were recorded at 42 days of age.

\section{3-Blood sampling:}

Blood samples were collected from the 2 groups, and divided into two portions; the first one was collected in plain tubes, for separation of serum and kept frozen at $-20^{\circ} \mathrm{C}$ tell use. The second blood sample was collected in heparinized tubes and was used for separation of PBM according to (Grievink et al., 2016). 4-Evaluation of humeral immune response of chicks:

Humeral immune response was evaluated at $1^{\text {st }}, 2^{\text {nd }}, 3^{\text {rd }}$ and $4^{\text {th }}$ week by detecting antibody titer against ND and AI virus vaccine by haemagglutination inhibition test according to (Miller, 2013).

5-Estimation of Innate immune response:

\section{1-Determination of phagocytic} activity:

The phagocytic activity of PBM was assessed according to Elmowalid (2012), at $1^{\text {st }}, 2^{\text {nd }}, 4^{\text {th }}$ and $6^{\text {th }}$ week of age. The results were expressed as phagocytic percentage (number of phagocytic monocytes /total number of monocytes) and phagocytic index (the main of engulfed Candida albicans blastospores per monocyte).

\section{2-Fungicidal} activity (Intracellular survival assay):

An intracellular survival assay was used to measure the fungicidal activity of PBM at $2^{\text {nd }}, 4^{\text {th }}$ and $6^{\text {th }}$ week of age, according to (Peck, 1985).

\section{3-Nitric oxide assay:}

Nitric oxide production was measured in monocytes culture media using Griess reagent at $1^{\text {st }}$, $2^{\text {nd }}, 4^{\text {th }}$ and $6^{\text {th }}$ week as described by (Blond et al., 2000).

\section{4-Reactive oxygen species production:}

The reactive oxygen species production of monocytes were determined using Nitro blue tetrazolium reduction test at $2^{\text {nd }}, 3^{\text {rd }}$ and $6^{\text {th }}$ week of age, as described by (Anderson and Siwicki, 1995).

\section{6-Challenge Test:}

Multidrug resistant virulent $E$. coli strain (obtained from animal health institute,Dokki) was used at the end of the experiment (42 day of age ),for challenge test. The clinical symptoms were recorded since the first day of chicken inoculation for calculation of morbidity and mortality rate, the survived chickens were slaughtered and the internal organs were harvested and prepared to determine total CFU count in each organ of each chicken in each experimental group.

\section{7-Statistical analysis:}

The data were given as means \pm S.E. The statistical analysis was done using the One Way ANOVA. The significant $(* \boldsymbol{P})$ values were 
taken as $\quad \boldsymbol{P} \leq \mathbf{0 . 0 5}$ (McCredie et al., 2006).

Results

1-Effect of dietary supplementation with lactoferrin on growth performance of broiler chickens:

The results shown in Table (1) revealed that chickens fed lactoferrin supplemented diet for 42 days showed a significant increase in final body weight and body weight gain compared to control group.

2-Effect of

dietary supplementation with lactoferrin on humoral immune responses of broiler chickens:

2.1-Antibody titers against ND and AI viruses' vaccine of broiler chickens:

As shown in Table (2) chickens fed lactoferrin supplemented diet (G2) showed significant increase in antibody titer of $\mathrm{ND}$ and $\mathrm{AI}$ vaccines at $2^{\text {nd }}$ and $3^{\text {rd }}$ and $4^{\text {th }}$ week compared to the control group.

3-Effect of dietary supplementation of lactoferrin on the innate immunity:

3.1- phagocytic activity of peripheral blood monocyte cell:

The phagocytic activity of PBM of chickens fed lactoferrin supplemented diet (G2) showed significant increase in the phagocytic $\%$ and index at $4^{\text {th }}$ and $6^{\text {th }}$ week compared to the control group (G1) as shown in Table (3) and photo (1).
3.2- Fungicidal activity of peripheral blood monocyte cells: Fungicidal \% of the PBM reveled significant increase in (G2), chickens fed lactoferrin supplemented diet, compared to control group at $2^{\text {nd }}, 4^{\text {th }}$ and $6^{\text {th }}$ weeks $(\boldsymbol{P}<0.05)$ as shown in Table (4)

3.3- Nitric oxide production (NO) $(\mu \mathrm{mol} / \mathrm{ml})$ :

Nitric oxide concentration in PBM culture media of chickens fed lactoferrin supplemented diet (G2), showed a significant increase in NO production at $6^{\text {th }}$ weeks compared with the control group $(\boldsymbol{P}<0.05)($ Table 4).

\section{4- Reactive oxygen species} (ROS) production (OD):

The nitro blue tetrazolium reduction test of PBM of chickens fed lactoferrin supplemented diet showed a significant increase on ROS production at $6^{\text {th }}$ weeks compared to control group $(\boldsymbol{P}<$ 0.05 ) (Table 4 and photo. 2).

4-Effect of lactoferrin on susceptibility to infections (challenge test):

Clinical signs of E.coli infection were observed on both challenged groups within 2-3 days post infection, including; fever, ruffling feather, weight loss, and diarrhea, which were more severe in control group $(\mathrm{G} 1)$ than group fed lactoferrin supplemented $\operatorname{diet}(\mathrm{G} 2)$, as shown in Table (5), morbidity percent recorded $80 \%$ in control group, meanwhile it was $(33.3 \%)$ in lactoferrin supplemented diet 
group. Mortality rate was $(60 \%)$ in the control group during the course of infection, meanwhile it was $(13.3 \%)$ in lactoferrin supplemented diet group .As shown in Table (6) there was a significant reduction in E. coli count in the spleen, liver and intestine of chickens fed lactoferrin supplemented diet comparing with the control group.

Table (1): Effect of dietary supplementation of lactoferrin on growth performance of broiler chicks:

\begin{tabular}{|c|c|c|c|}
\hline Group & Initial body weight $(\mathrm{g})$ & Final body weight $(\mathrm{g})$ & body weight gain $(\mathrm{g})$ \\
\hline Control & $46.00 \pm 0.67^{\mathrm{b}}$ & $1779.40 \pm 5.89^{\mathrm{b}}$ & $1731.79 \pm 5.05^{\mathrm{b}}$ \\
\hline Lactoferrin & $45.49 \pm 0.43^{\mathrm{a}}$ & $2221.8 \pm 2.64^{\mathrm{a}}$ & $2176.28 \pm 2.40^{\mathrm{a}}$ \\
\hline
\end{tabular}

*Data are presented as (means \pm S.E) *Means with different superscript letters in the same column are significantly different at $(\boldsymbol{P} \leq 0.05)$.

Table (2): Effect of dietary supplementation with lactoferrin on the antibody titer (log2 HI titer) against Newcastle and Avian influenza viruses at different ages:

\begin{tabular}{|c|c|c|c|c|c|c|c|c|}
\hline Type & \multicolumn{4}{|c|}{ ND antibody } & \multicolumn{4}{|c|}{ AIV antibody } \\
\hline Group & $1^{\text {st }}$ week & $2^{\text {nd week }}$ & $3^{\text {rd }}$ week & $4^{\text {th }}$ Week & $1^{\text {st }}$ week & $2^{\text {nd }}$ week & $3^{\text {rd week }}$ & $4^{\text {th }}$ week \\
\hline Control & $\begin{array}{c}4.26 \\
\pm 0.21^{\mathrm{a}} \\
\end{array}$ & $\begin{array}{c}4.26 \\
\pm 0.10^{\mathrm{b}} \\
\end{array}$ & $\begin{array}{c}5.89 \\
\pm 0.17^{\mathrm{b}} \\
\end{array}$ & $\begin{array}{c}6.47 \\
\pm 0.23^{\mathrm{b}} \\
\end{array}$ & $\begin{array}{c}5.19 \\
\pm 0.23^{\mathrm{a}} \\
\end{array}$ & $\begin{array}{c}2.26 \\
\pm 0.07^{\mathrm{b}} \\
\end{array}$ & $\begin{array}{c}3.77 \\
\pm 0.32^{\mathrm{b}} \\
\end{array}$ & $\begin{array}{c}4.81 \\
\pm 0.21^{\mathrm{b}} \\
\end{array}$ \\
\hline Lactoferrin & $\begin{array}{c}4.17 \\
\pm 0.29^{\mathrm{a}}\end{array}$ & $\begin{array}{c}5.27 \\
\pm 0.12^{\mathrm{a}}\end{array}$ & $\begin{array}{c}6.42 \\
\pm 0.25^{\mathrm{a}}\end{array}$ & $\begin{array}{c}7.01 \\
\pm 0.17^{\mathrm{a}}\end{array}$ & $\begin{array}{c}5.91 \\
\pm 0.33^{\mathrm{a}}\end{array}$ & $\begin{array}{c}2.75 \\
\pm 0.10^{\mathrm{a}}\end{array}$ & $\begin{array}{c}4.62 \\
\pm 0.16^{\mathrm{a}}\end{array}$ & $\begin{array}{c}6.24 \\
\pm 0.21^{\mathrm{a}}\end{array}$ \\
\hline
\end{tabular}

*Data are presented as (means \pm S.E) *Mean with different superscript letters in the same column are significantly different at $(\boldsymbol{P} \leq 0.05)$.

Table (3): Effect of dietary supplementation with lactoferrin on Phagocytic $\%$ and index of the peripheral blood monocytes of broiler chickens:

\begin{tabular}{|c|c|c|c|c|c|c|c|c|}
\hline Type & \multicolumn{4}{|c|}{ Phagocytic \% } & \multicolumn{4}{|c|}{ Phagocytic index } \\
\hline $\mathbf{G r}$ & 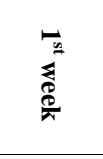 & 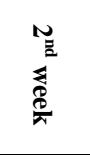 & 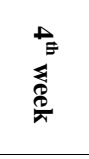 & $\begin{array}{l}\hat{\bar{E}} \\
\frac{\not}{\not} \\
\frac{\infty}{\pi}\end{array}$ & 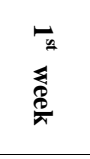 & $\begin{array}{l}\widetilde{\equiv} \\
\text { 足 } \\
\frac{\mathbb{Z}}{\alpha}\end{array}$ & $\begin{array}{l}\vec{E} \\
\vec{D} \\
\frac{D}{2}\end{array}$ & $\begin{array}{l}\hat{\equiv} \\
\frac{\partial}{2}\end{array}$ \\
\hline Control & $\begin{array}{c}55.00 \pm \\
2.85^{\mathrm{a}}\end{array}$ & $\begin{array}{r}53.00 \pm \\
2.66^{\mathrm{a}}\end{array}$ & $\begin{array}{l}57.00 \pm \\
2.19^{\mathrm{b}}\end{array}$ & $\begin{array}{c}56.00 \pm \\
1.54^{\mathrm{b}}\end{array}$ & $\begin{array}{l}3.10 \pm \\
0.17^{\mathrm{a}}\end{array}$ & $\begin{array}{l}3.40 \pm \\
0.17^{\mathrm{a}}\end{array}$ & $\begin{array}{l}2.90 \pm \\
0.10^{\mathrm{b}}\end{array}$ & $\begin{array}{l}2.80 \pm \\
0.09^{\mathrm{b}}\end{array}$ \\
\hline Lactoferrin & $\begin{array}{c}56.00 \\
\pm 3.56^{\mathrm{a}}\end{array}$ & $\begin{array}{c}57.00 \\
\pm 3.00^{\mathrm{a}}\end{array}$ & $\begin{array}{r}61.00 \\
\pm 2.81^{\mathrm{a}}\end{array}$ & $\begin{array}{r}63.00 \\
\pm 1.91^{\mathrm{a}}\end{array}$ & $\begin{array}{c}3.30 \\
\pm 0.16^{\mathrm{a}}\end{array}$ & $\begin{array}{c}3.20 \\
\pm 0.17^{\mathrm{a}}\end{array}$ & $\begin{array}{c}4.30 \\
\pm 0.17^{\mathrm{a}}\end{array}$ & $\begin{array}{c}4.70 \\
\pm 0.29^{\mathrm{a}}\end{array}$ \\
\hline
\end{tabular}

*Data are presented as (means \pm S.E) *Means with different superscript letters in the same column are significantly different at $(\boldsymbol{P} \leq 0.05)$. 
Table (4): Effect of dietary supplementation with lactoferrin on Fungicidal activity, Nitric oxide production and reactive oxygen species (ROS) production:

\begin{tabular}{|c|c|c|c|c|c|c|c|c|c|}
\hline Test & \multicolumn{3}{|c|}{ Fungicidal \% } & \multicolumn{3}{|c|}{$\mathrm{NO}(\mu \mathrm{mol} / \mathrm{ml})$} & \multicolumn{3}{|c|}{$\operatorname{ROS}(O D)$} \\
\hline Age & $\begin{array}{c}2^{\text {nd }} \\
\text { week }\end{array}$ & $\begin{array}{c}4^{\text {th }} \\
\text { week }\end{array}$ & $\begin{array}{c}6^{\text {th }} \\
\text { week }\end{array}$ & $2^{\text {nd }}$ week & $4^{\text {th }}$ week & $6^{\text {th }}$ week & $\begin{array}{c}2^{\text {nd }} \\
\text { week }\end{array}$ & $\begin{array}{c}4^{\text {th }} \\
\text { week }\end{array}$ & $6^{\text {th }}$ week \\
\hline Control & $\begin{array}{r}43.00 \\
\pm 2.48^{\mathrm{b}}\end{array}$ & $\begin{array}{l}53.00 \\
\pm 2.24^{\mathrm{b}}\end{array}$ & $\begin{array}{l}52.00 \\
\pm 1.54^{\mathrm{b}}\end{array}$ & $\begin{array}{l}23.90 \\
\pm 0.34^{\mathrm{a}}\end{array}$ & $\begin{array}{c}32.10 \\
\pm 1.36^{\mathrm{a}}\end{array}$ & $\begin{array}{c}29.50 \\
\pm 1.28^{\mathrm{b}}\end{array}$ & $\begin{array}{c}0.034 \\
\pm 0.003 \\
\mathbf{a}\end{array}$ & $\begin{array}{c}0.038 \\
\pm 0.002 \\
\mathrm{a}\end{array}$ & $\begin{array}{c}0.037 \\
\pm 0.002^{\mathrm{b}}\end{array}$ \\
\hline Lactoferrin & $\begin{array}{r}78.00 \\
\pm 1.83^{\mathrm{a}}\end{array}$ & $\begin{array}{r}79.00 \\
\pm 1.54^{\mathrm{a}}\end{array}$ & $\begin{array}{l}87.00 \\
\pm 2.57^{\mathrm{a}}\end{array}$ & $\begin{array}{l}21.60 \\
\pm 0.31^{\mathrm{a}}\end{array}$ & $\begin{array}{c}33.50 \\
\pm 1.48^{\mathrm{a}}\end{array}$ & $\begin{array}{r}34.90 \\
\pm 1.56^{\mathrm{a}}\end{array}$ & $\begin{array}{c}0.033 \\
\pm 0.001 \\
\mathbf{a}\end{array}$ & $\begin{array}{c}0.042 \\
\pm 0.003 \\
\mathbf{a}\end{array}$ & $\begin{array}{c}0.057 \\
\pm 0.001^{\mathrm{a}}\end{array}$ \\
\hline
\end{tabular}

*Data are presented as (means \pm S.E) *Mean with different superscript letters in the same column are significantly different at $(\boldsymbol{P} \leq 0.05)$.

Table (5): Effect of dietary supplementation with lactoferrin on mortality and morbidity rate of broiler chickens after challenge with E.coli:

\begin{tabular}{|c|c|c|}
\hline Group Parameter & Control & Lactoferrin \\
\hline Total No & 15 & 15 \\
\hline $\begin{array}{c}\text { Morbidity( } \\
\text { number) }\end{array}$ & $12(80 \%)$ & $5(33.3 \%)$ \\
\hline Mortality( number) & $9(60 \%)$ & $2(13.3 \%)$ \\
\hline
\end{tabular}

Table (6): Effect of dietary supplementation of lactoferrin on CFU/ml of E.coli in involved organs of broiler chickens:

\begin{tabular}{|c|c|c|c|}
\hline Qrgan & Spleen & Liver & Intestine \\
\hline Group & & & $16 \times 10^{6} \pm 1154700^{\mathrm{a}}$ \\
\hline Control & $14 \times 10^{6} \pm 577530^{\mathrm{a}}$ & $21 \times 10 \pm 11574^{\mathrm{a}}$ & \\
\hline Lactoferrin & $4 \times 10^{6} \pm 288675^{\mathrm{b}}$ & $4 \times 10^{3} \pm 288.67^{\mathrm{b}}$ & $7 \times 10^{3} \pm 288.68^{\mathrm{b}}$ \\
\hline
\end{tabular}

*Data are presented as (means \pm S.E) *Mean with different superscript letters in the same column is significantly different at $(\boldsymbol{P} \leq 0.05)$. 


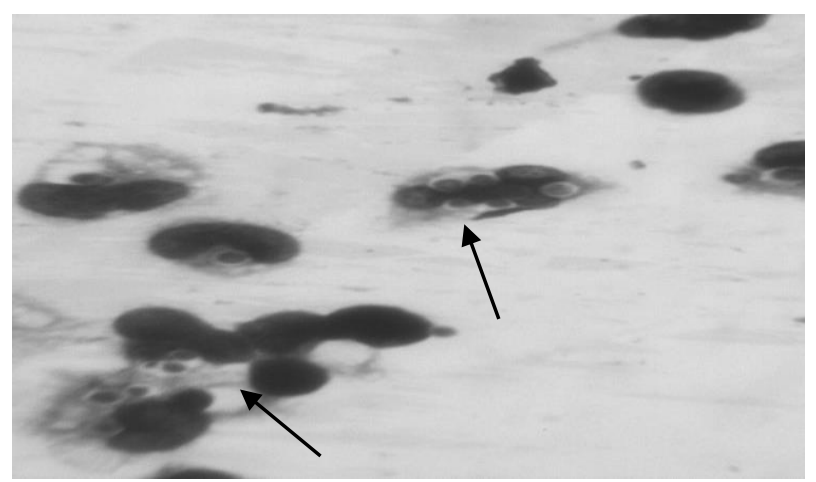

Photo (1) Peripheral blood monocytes cells of broiler chickens fed lactoferrin supplemented diet, engulfed Candida albicans (Giemsa stain X 100).

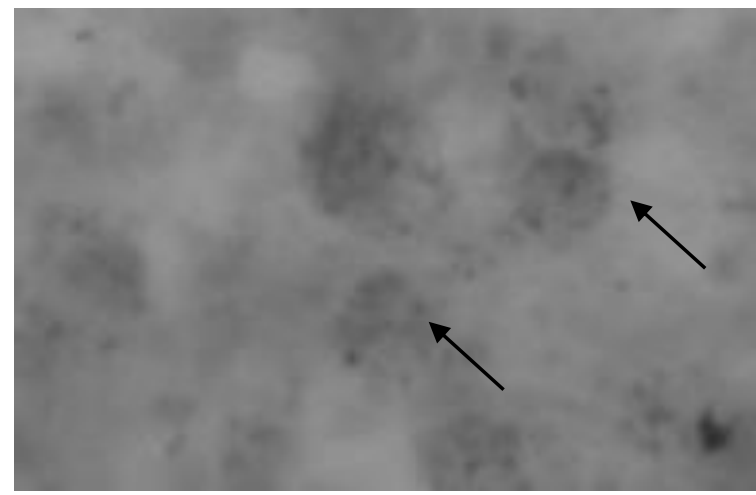

Photo (2): Peripheral blood monocytes cells of broiler chickens fed lactoferrin supplemented diet have blue formazne deposit granules (Leishman's stain 100x).

\section{Discussion}

In the present work, lactoferrin provided a significant improvement in the final body weight and body weight gain as shown in Table (1), these results are in agreement with the findings of (Humphrey et al., 2002). It was recorded that, oral administration of lactoferrin has been used to stimulate growth performance of the treated animal (Shan et al., 2007).
In order to evaluate the effect of dietary supplementation of lactoferrin on humoral immune response of broiler chickens, antibody titers against ND and AIVvaccines were determined. In the present work, broiler chicks fed supplemented diet with lactoferrin showed significant increase in antibody titer against ND and AIV (Table 2). These findings are in accordance with Kumari and Sahoo (2006). 
Regarding to phagocytic activity of PBM (Table 3 and Fig.1), there is a marked increase in the phagocytic $\%$ and index in lactoferrin group compared to the control group. These results are in agreement with those obtained by (Arnaud and Evan, 2003; Jenssen and Hancock, 2008). Lactoferrin is promoting the function of phagocytic cells by enhancing phagocytic activity and modifying production of reactive oxygen species (Ward et al., 2008) and activating macrophages through increasing cytokine and NO production and limiting intracellular pathogen proliferation (Puddu et al.,2007).

The fungicidal $\%$ of PBM showed a significant increase in lactoferrin treated group compared to control group (Table 4). These results are supported with those obtained by Cirioni et al. (2000) and Lupetti et al. (2008) who reported that lactoferrin has a significant antifungal activity.

In the current study, the nitro blue tetrazolium test (NBT) was used to investigate the effect of lactoferrin on production of reactive oxygen species by PBM, there is a marked increase in ROS at $6^{\text {th }}$ week compared to control group. These findings agree with those obtained by Anand et al. (2015) who revealed that there was a significant increase in production of reactive oxygen species, phagocytic activity, and Toll-like receptor expression in host cells incubated with iron- saturated lactoferrin when compared with control group.

The chickens fed supplemented diet with Lactoferrin(G2) showed significant elevation in $\mathrm{NO}$ at $6^{\text {th }}$ week of age, This result agree with those obtained by Sorimachi et al.(1997) who reported that lactoferrin, activates macrophages and induces IL-8, TNF- $\alpha$ and NO production. Lactoferrin activate macrophages through increasing cytokine and NO production and limiting intracellular pathogen proliferation (Longhi et al., 2004 and Puddu et al., 2007).

In the present work, the effect of dietary supplementation of lactoferrin on susceptibility to infections was investigated by challenge test as shown in Tables (5 and 6); the morbidity rate was $(80.3 \%)$ in control group, while it was $(46.4 \%)$ in lactoferrin supplemented group. The mortality rate was $(60 \%)$ in the control, while it was $(26.7 \%)$ chickens died in the lactoferrin dietary supplemented group. The results revealed that there was a significant reduction in E. coli count in the spleen, liver and intestine of chickens fed on supplemented ration with lactoferrin when compared with the control group. These findings are in accordance with that reported by Ochoa et al. (2008). Lactoferrin was found to degrade and impair the function of the surface expressed virulence factors of $E$. coli, thereby decreasing their ability to adhere to or invade host cells. 
Furthermore, LF has been found to prevent biofilm formation at subinhibitory concentrations by stimulating bacterial motility, which causes the bacteria to wander across the surface instead of forming cell clusters (Singh et al., 2002) . Moreover, lactoferrin has antimicrobial activity and capability of binding components of bacterial cell walls (LPS) or their receptors, lactoferrin is also bacteriostatic because it sequesters environmental iron, an essential growth factor of bacteria (Legrand et al., 2005).

In conclusion, The current study demonstrated the beneficial effect of the dietary supplementation of lactoferrin as it could stimulate humeral immunity against ND and AI vaccine, as well as enhance the innate immunity by stimulating the PBM function as phagocytic activity, Fungicidal activity and ROS \& NO production .Also lactoferrin favored the reduction of E. coli lesions, morbidity, mortality, and number of $E$. coli in the spleen, liver and intestine of broiler chickens.

\section{References}

Abbas, A.K. and Litchman, A.H. (2005): Innate immunity. In: Abbas AK, Litchman AH, Pillai S. Cellular and molecular immunology. $5^{\text {th }}$ ed. Amsterdam: Elsevier Health Sciences.

Adlerova, L. Bartoskova, A. and Faldyna, M. (2008): Lactoferrin, a reviewVeterinarni Medicina, 53 (9): 457-468.
Anand N., Kanwar, R.K., Dubey M.L., Vahishta R.K., Sehgal R., Verma A.K. and Kanwar J.R. (2015): Effect of lactoferrin protein on red blood cells and macrophages: mechanism of parasite-host interaction. Drug Des Devel Ther., 27: 9:3821-35.

Anderson, D.P and Siwicki, A.K. (1995): Basic haematology and serology for fish health programs. pp. 185-202. In:M. Shariff, J.R. Author and R.P. Subasinghe. (eds.) Diseases in Asian Aquaculture II, Fish Health Section, Asian Fisheries Society, Manila, Philippines.

$\begin{array}{lrr}\text { Arnaud S. and Evans } & \text { R.W. } \\ \text { (2003): } & \text { Lactoferrin } & \text { a } \\ \text { multifunctional protein } & \text { with } \\ \text { antimicrobial properties. } & \text { Mol }\end{array}$
Immunol.40:395-405.

Blond, D.; Raoul, H.; Grand R.m and Dormont D. (2000): Nitric oxide synthesis enhances human immunodeficiency virus replication in primary human macrophages. $\mathrm{J}$. Virol., 74:8904-8912.

Cirioni O., Giacometti A., Barchiesi F. and Scalise G. (2000): Inhibition of growth of Pneumocystis carinii by lactoferrins alone and in combination with pyrimethamine, clarithromycin and minocycline. The Journal of Antimicrobial Chemotherapy, 46, 577582.

Elmowalid, G., (2012): A simple method for generation of functional sheep peripheral blood monocytesderived-macrophages in vitro. Global veterinaria 9 (5) : 590-599. 
Grievink, H.W., Luisman T, Kluft $C$, Moerland $M$. and Malone K.E., (2016): Comparison of three isolation techniques for human peripheral blood mononuclear cells: Cell recovery and viability, population composition, and cell functionality," Biopreservation and Biobanking. Oct;14(5):410-415. Epub 2016 Apr 22.

Humphrey, B. D., Huang, N. and Klasing, K. C. (2002): Rice Expressing Lactoferrin and Lysozyme Has Antibiotic-Like Properties When Fed to Chicks. J. Nutr. 132: 1214-1218.

Jenssen H. and Hancock R.E. (2008): Antimicrobial properties of lactoferrin. Biochimie. 2009 Jan;91(1):19-29. doi: 10.1016/j.biochi.2008.05.015. Epub 2008 Jun 5.

Kumari, J. and Sahoo, P.K.(2006): Dietary beta-1,3 glucan potentiates innate immunity and disease resistance of Asian catfish, Clarias batrachus

(L.) .https://www.ncbi.nlm.nih.gov/pub med/16436120 J Fish disease 2006 Feb;29(2):95-101.

Lee, E., Hall, R.A and Lobigs, M.(2004): Common E protein determinants for attenuation of glycosaminoglycan-binding variants of Japanese encephalitis and West Nile viruses.J. Virol., 78 (15) (2004), pp. 8271-8280.

Legrand, D.; Elass, E.; Carpentier, M. and Mazurier, J. (2005): Lactoferrin: a modulator of immune and inflammatory responses. Cellular and Molecular Life Sciences, 62: 2549-2559.

Longhi C, Conte M.P, Penta M, Cossu A, Antonini G. and Superti F. (2004): Lactoferricin influences early events of Listeria monocytogenes infection in THP-1 human macrophages. $\mathrm{J}$ Med Microbiol.,53:87.

Lupetti A, van Dissel J.T, Brouwer C.P. and Nibbering (2008): PH. Human antimicrobial peptides' antifungal activity against Aspergillus fumigatus. Eur $\mathrm{J}$ Clin Microbiol Infect Dis.

Masihi, K.N. (2001): Fighting infection using immunomodulatory agents. Expert Opin Biol Ther., 1 (4): 641-53.

McCreadie, J.W. Adler, P.H. , Hamada, N. and Grillet M.E.(2006): Sampling and statistics in understanding distributions of black fly larvae (Diptera: Simuliidae)Acta Entomol. Serbica (Suppl) (2006), pp. 89-96.

Miller PJ, Koch G.(2013): Newcastle Disease. In: Swayne DE, editor. Diseases of poultry. 13th ed. Oxford, UK: Wiley-Blackwell . pp. 68-107.Elmowalid, Gamal A., 2012. Simple method for generation of functional sheepmonocytesderived macrophages in vitro. Global Veterinaria 9 (5), 590-599.

Ochoa, T.J, Chea-Woo E, Campos,M., Pecho, I, Prada, A., Mc Mahon, R.J. and Cleary, T.G. (2008): Impact of lactoferrin supplementation on growth and prevalence of Giardia colonization 
in children. Clin Infect Dis., 46:1881-1883.

Opal, S.M. and Esmon, C.T. (2003): Bench to bedside review: Functional relationship between coagulation and the innate immune response and their respective role in the pathogenesis of sepsis. Critical Care, 7 (1): 23-28.

Porchezhian, T. and Punniamurthy, N. (2006): Effect of Oral Levamisole Hydrochloride on Humoral Immune Response and Serum proteins of Broilers. Journal of Animal and Veterinary Advances, 5 (10): 873-874.

Puddu P, Carollo M.G, Belardelli F, Valenti $P$ and Gessani S.(2007): Role of endogenous interferon and LPS in the immunomodulatory effects of bovine lactoferrin in murine peritoneal macrophages. $\mathrm{J}$ Leukoc Biol.,82:347-53.

Robert J. Hughes (2009): An integrated approach to understanding gut function and gut health of chickens Sardi Australian poultry CRC final report.Program (1)Project No: Poultry CRC 05-2. 2009 Australian Poultry CRC Pty Ltd.blood mononuclear cells. J. Leukoc. Biol., 68: 503-510.
Shan T, Wang Y, Wang Y, Liu J and $\mathrm{Xu} \mathrm{Z}$., (2007):Effect of dietary lactoferrin on the immune functions and serum iron level of weanling piglets. J Anim Sci., 85:2140-2146. Singh, P.K.; Parsek, M.R.; Greenberg, E.P. and Welsh, M.J. (2002): A component of innate immunity prevents bacterial biofilm development. Nature, 417: 552-555. Sorimachi, K.; Akimoto, K.; Hattori, Y.; Leiri, T. and Niwa, A. (1997): Activation of macrophages by lactoferrin : secretion of TNF a, IL-8 and NO. Biochem.Mol . Biol. Int.,43: 79-87.

Vander V. W.; Blijlevens, N.M. and Donnelly, J.P. (2007): The Potential Role of Lactoferrin and Derivatives in the Management of Infectious and Inflammatory Complications of Hematology Patients Receiving a Hematopoietic Stem Cell Transplantation. Transplant Infectious Disease, 10 (2): 68-71.

Ward P.P, Mendoza-Meneses M, Park P.W and Conneely O.M.(2008): Stimulus-dependent impairment of the neutrophil oxidative burst response in lactoferrin-deficient mice. Am J Pathol.;172:1019-29.] 
تقييم تاثير مستخلص اللاكتوفيرين كمعل مناعي علي الاستجابة المناعية فى دجاج التسمين

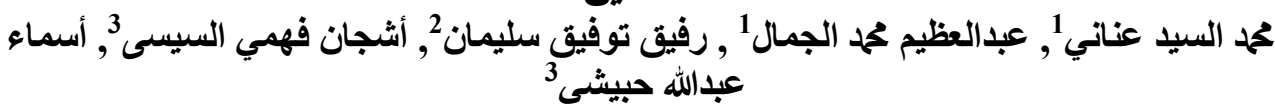

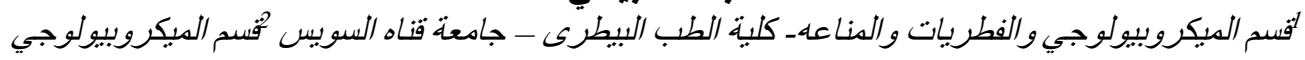

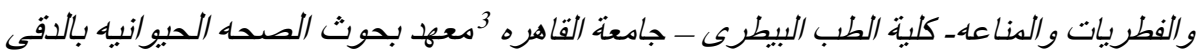

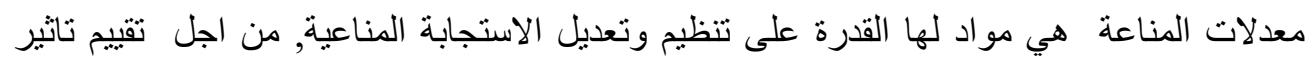

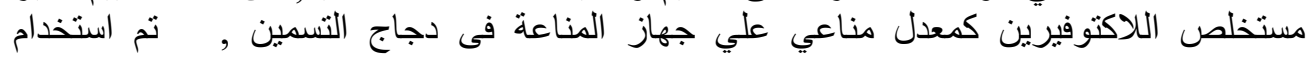

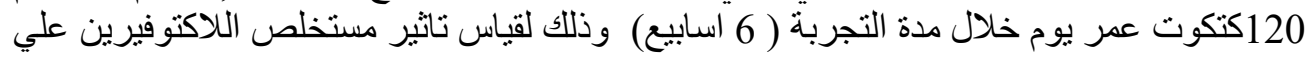

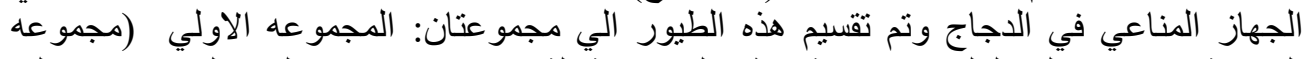

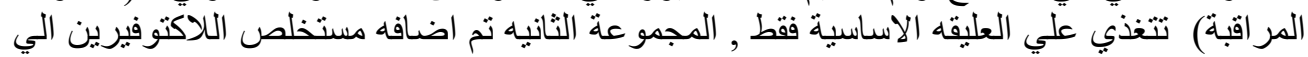

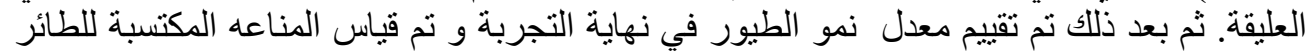

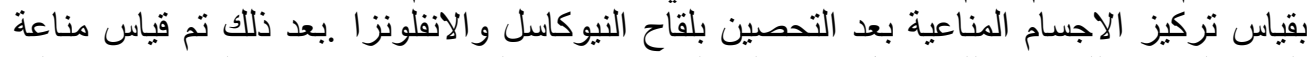

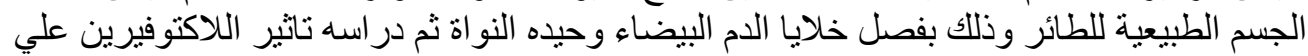

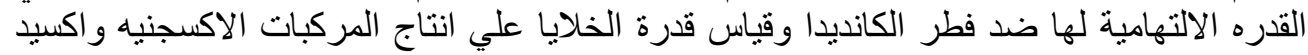

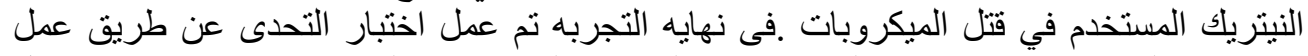

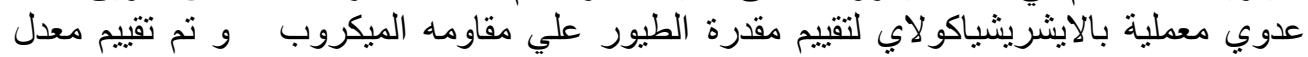

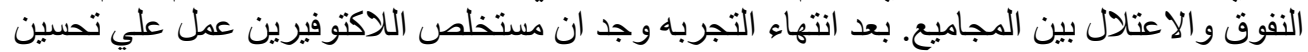

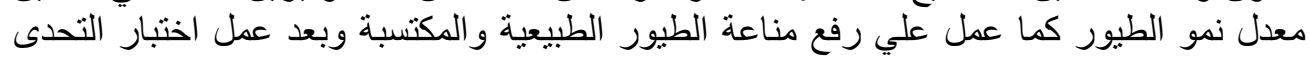

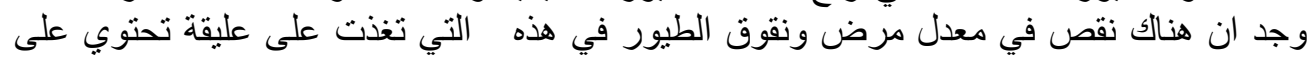

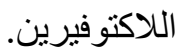

